JIKAP PGSD: Jurnal IImiah Illmu Kependidikan

Vol,3. No,2. Tahun 2019

e-ISSN: 2597-4440 dan p-ISSN: 2597-4424

This work is licensed under a Creative Commons Attribution

4.0 International License

\title{
Mengembangkan Bakat Kemandirian Murid Melalui Penerapan Strategi Outdoor Learning Dan Indoor Learning Pada TK Pertiwi Pompanua Kabupaten Bone
}

\author{
Rosnah \\ Dinas Pendidikan Kabupaten Bone \\ Email: rosnah@gmail.com
}

\begin{abstract}
Abstrak.Penelitian ini bertujuan untuk mengetahui perkembangan kemandirian siswa dalam memahami materi pelajaran dan upaya dalam meningkatkan hasil belajar siswa dengan menggunakan metode bermain. Penelitian ini termasuk jenis penelitian tindakan kelas. Pendekatan yang digunakan adalah pendekatan kualitatif. Subjek dalam penelitian ini adalah siswa kelompok A TK Pertiwi Pompanua Kabupaten Bone semester ganjil Tahun Pelajaran 2018/2019 yang berjumlah 15 murid. Objek dalam penelitian ini adalah penerapan strategi outdoor dan indoor learning dalam meningkatkan hasil belajar siswa. Alat yang digunakan untuk mengumpulkan data adalah test yaitu tes awal, pos tes I, pos tes II, wawancara dan observasi. Penelitian ini terdiri dari dua siklus. Upaya yang dilakukan memahami materi menggambar sesuai keinginan siswa, peneliti memberikan pembelajaran secara berkelompok. Dari pemberian tindakan dengan pembelajaran menggunakan metode bermain pada siklus I dan II diperoleh data tentang nilai rata-rata dan tingkat ketuntasan belajar siswa. Pada tes awal nilai rata-rata siswa 1.93 , pada saat pos tes I nilai rata-rata siswa meningkat menjadi 2.53 dan pada waktu pos tes II nilai rata-rata siswa meningkat menjadi 3.33. Sementara untuk ketuntasan pada tes awal hanya sebesar $20 \%$, pada siklus I meningkat menjadi $60 \%$, bahkan pada siklus II meningkat tajam menjadi $86.67 \%$. Berarti hasil yang diperoleh siswa pada siklus II sudah mencapai tingkat ketuntasan secara klasikal, yakni $\geq 85 \%$ yang mencapai nilai tuntas $\geq$ bintang 3 . Selanjutnya sikap kemandirian siswa, pada pra siklus 13.33, lalu pada siklus I meningkat menjadi 53.33, dan pada siklus II sebesar $86.67 \%$. Jadi dapat disimpulkan bahwa penggunaan metode bermain dapat meningkatkan kemandirian siswa dalam memahami materi pelajaran dan meningkatkan hasil belajar siswa.
\end{abstract}

Kata kunci: metode bermain, kemandirian, outdoor learning dan indoor learning

Abstract. This study aims to determine the development of students' independence in understanding the subject matter and efforts to improve student learning outcomes using the play method. This research is a type of classroom action research. The approach used is a qualitative approach. The subjects in this study were group A students of Pertiwi Pompanua Kindergarten, Bone District, odd semester 2018/2019 Academic Year, totaling 15 students. The object in this study is the application of outdoor and indoor learning strategies in improving student learning outcomes. The tool used to collect data is a test that is the initial test, test post I, test post II, interview and observation. This study consisted of two cycles. Efforts made to understand drawing material according to the wishes of students, researchers 
JIKAP PGSD: Jurnal Ilmiah Ilmu Kependidikan

provide learning in groups. From giving actions to learning using the playing method in the first and second cycles, data were obtained about the average value and level of mastery of student learning. On the initial test, the average score of students was 1.93, at the time of the test post I the average score of students increased to 2.53 and at the time of the test post-II the average score of students increased to 3.33. While for completeness in the initial test only by $20 \%$, the first cycle increased to $60 \%$, even in the second cycle increased sharply to $86.67 \%$. This means that the results obtained by students in the second cycle have reached the level of completeness in classics, namely $\geq 85 \%$ which reached a complete value of intang3 star. Furthermore, the attitude of students' independence, at the pre-cycle of 13.33, then in the first cycle increased to 53.33 , and in the second cycle $86.67 \%$. So it can be concluded that the use of playing methods can increase students' independence in understanding the subject matter and improving student learning outcomes.

Keywords: method of play, independence, outdoor learning \& indoor learning

\section{PENDAHULUAN}

Pendidikan terjadi dengan adanya suatu kegiatan pembelajaran, baik formal maupun informal. Pembelajaran merupakan bentuk penyelenggaraan pendidikan yang memadukan secara sistematis dan berkesinambungan suatu kegiatan. Pembelajaran di Taman Kanak-kanak bersifat spesifik didasarkan pada tugas-tugas pertumbuhan dan perkembangan anak dengan mengembangkan aspek-aspek perkembangan yang meliputi moral dan nilai-nilai agama, sosial, emosional, kemandirian, berbahasa, kognitif, fisik/motorik dan seni.

Kemandirian anak sebagai salah satu aspek perkembangan Bidang Pengembangan Pembiasaan Program Pembelajaran Taman Kanakkanak Kurikulum 2004 mempunyai peran penting, karena aspek kemandirian dimaksudkan untuk membina anak agar dapat menolong dirinya sendiri dalam rangka kecakapan hidup (life skill), serta memperoleh keterampilan dasar yang berguna untuk kelangsungan hidup anak. Melalui pemberian rangsangan, stimulasi dan bimbingan, diharapkan akan meningkatakan perkembangan perilaku dan sikap melalui pembiasaan yang baik, sehingga akan menjadi dasar utama dalam pembentukan pribadi anak sesuai dengan nilainilai yang ada di masyarakat.

Pembelajaran kemandirian anak yang diarahkan untuk mengemgkan kecakapan hidup melalui kegiatan-kegiatan konkrit yang dekat dengan kehidupan anak sehari-hari mempunyai peranan penting. Namun keberhasilan kegiatan belajar mengajar yang mengembangkan aspek kemandirian anak sering meresahkan guru
Kelompok A TK Pertiwi Pompanua Kabupaten Bone. Berdasarkan pengamatan mulai awal masuk sekolah sampai pertengahan semester I Tahun Pelajaran 2018/2019 menunjukkan bahwa kemandirian murid Kelompok A masih kurang. Kondisi ini diindikasikan dengan anak tidak mau menerima tugas dari guru, dalam mengerjakan tugas tidak tuntas, anak kurang percaya diri sehingga tidak mampu mengerjakan tugas sendiri dan selalu meminta bantuan guru, serta kurang antusias dalam kegiatan belajar mengajar. Oleh karena itu, perlu adanya upaya untuk mengatasi masalah tersebut. Salah satunya adalah dengan menggunakan metode pembelajaran.

Menurut Nasution "metode adalah suatu cara yang digunakan untuk melaksanakan kegiatan-kegiatan dalam suatu tugas atau pekerjaan agar dapat mencapai tujuan sesuai dengan yang ditetapkan". Sedangkan menurut Ahmadi (2005:52) "metode adalah suatu pengetahuan tentang cara-cara mengajar yang dipergunakan oleh seorang guru atau instruktur". Sedangkan dalam Kamus Besar Bahasa Indonesia metode adalah "cara kerja yang bersistem untuk memudahkan pelaksanaan suatu kegiatan guna mencapai tujuan yang ditetapkan.

Pengertian metode di atas mengisyaratkan bahwa penggunaan metode dalam proses pembelajaran menjadi sangat penting. Karena itu, makin tepat metode yang digunakan oleh guru dalam mengajar, diharapkan makin efektif dan efisien dalam pencapaian tujuan pembelajaran. Tentunya tetap memperhatikan faktor-faktor lain seperti; faktor guru, faktor siswa, faktor situasi (lingkungan belajar), media, dan lain-lain. 
Sehubungan dengan penggunaan metode, salah satu cara untuk mengembangkan kemampuan dan kemandirian anak adalah dengan bermain Menurut Plato anak-anak akan lebih mudah mempelajari aritmatika dengan cara permainan. Ia menyadari dan melihat pentingnya nilai praktis dari bermain. Sedangkan Sudono (2000:1) mengemukakan bahwa "bermain adalah suatu kegiatan yang dilakukan dengan atau tanpa mempergunakan alat yang menghasilkan pengertian atau memberikan informasi, memberi kesenangan maupun mengembangkan imajinasi anak".

Dengan bermain anak bisa mengembangkan potensi yang ada dalam dirinya, anak-anak akan lebih senang dan menjadikan si anak lebih aktif. Sebagaimana dikemukakan oleh Mayke (Sudono, 2000:3) "belajar dengan bermain akan memberi kesempatan kepada anak untuk memanipulasi, mengulang-ulang, menemukan sendiri, bereksplorasi serta mempraktekkannya".

Dalam proses pembelajaran guru hendaknya memberikan kebebasan kepada setiap anak didiknya untuk mengekspresikan apa yang ada dalam pemikiran mereka. Sebaiknya guru juga memberi kebebasan sesuai dengan sifat alami anak sehingga dalam mengembangkan kreatifitasnya anak tidak merasa takut dengan gurunya.

Dari penjelasan di atas diharapkan bahwa penggunaan metode bermain dalam proses pembelalajaran dapat meningkatkan kemampuan kemandirian anak dan juga meningkatnya hasil belajar siswa. Untuk itu, penulis tertarik untuk melaksanakan Penelitian Tindakan Kelas (PTK) dengan judul Mengembangkan Bakat Kemandirian Murid Melalui Penerapan Strategi Outdoor Learning Dan Indoor Learning Pada TK Pertiwi Pompanua Kabupaten Bone

\section{METODE PENELITIAN}

Jenis penelitian ini adalah penelitian tindakan kelas (Classroom Action Research). Pendekatan yang digunakan adalah pendekatan kualitatif yang berguna untuk mengungkapkan kesulitan belajar siswa dalam mengembangkan aspek kemandirian siswa serta cara untuk mengatasi kesulitan-kesulitan tersebut sebagai upaya atau usaha dalam meningkatkan hasil belajar siswa.

Penelitian ini dilaksanakan di TK Pertiwi Pompanua Kabupaten Bone pada semester ganjil tahun pelajaran 2018/2019 dengan subjek penelitian TK Pertiwi Pompanua Kabupaten Bone yang berjumlah 15 Murid .

Operasional variabel dalam penelitian ini yaitu variabel bebas dan variabel terikat. Variabel bebas dalam penelitian ini adalah pengajaran dengan menggunakan metode bermain. Sedangkan variabel terikat dalam penelitian ini adalah hasil belajar siswa pada materi pengembangan aspek kemandirian.

Penelitian ini terdiri dari dua siklus. Tiap siklus dilaksanakan sesuai dengan adanya perubahan yang ingin dicapai. Adapun langkahlangkah yang akan peneliti laksanakan yaitu:

1. Pembelajaran dilaksanakan dengan menggunkan metode bermain, dimana guru bertindak sebagai pengajar, fasilitator, dan motivator.

2. Selama proses belajar mengajar berlangsung, peneliti dan teman sejawat bertindak sebagai observer/ pengamat.

3. Observasi dilaksanakan pada saat pembelajaran berlangsung untuk melihat kelebihan dan kekurangan metode bermain.

4. Setelah proses belajar mengajar selesai dilaksanakan maka diadakan wawancara kepada siswa.

5. Untuk mengetahui ketuntasan belajar siswa, maka diadakan tes hasil belajar siswa mengenai pengembangan aspek kemandirian yang dapatkan setelah diberikan pembelajaran outdoor dan indoor dengan metode permainan.

Prosedur penelitian ini memiliki 4 tahapan, yaitu: (1) perencanaan, (2) pelaksanaan, (3) pengamatan, (4) refleksi (Arikunto, 2008). Sedangkan pengumpulan data dilaksanakan melalui tahapan tes, wawancara, dan observasi terhadap kelas yang menjadi subyek penelitian.

Adapun instrumen atau alat pengumpul data dalam penelitian yang digunakan dalam penelitian ini adalah tes berbentuk unjuk kerja, wawancara, dan observasi aktivitas siswa serta observasi aktivitas guru selama kegiatan belajar mengajar berlangsung.

Analisis data yang berkenaan dengan ketuntasan siswa (Jadmiko, 2003:19) dilakukan melalui tiga tahap yaitu reduksi data, paparan data dan penyimpulan data.

1. Reduksi data

Proses reduksi data dilakukan dengan menyeleksi, menyederhanakan, dan 
mentransformasikan data yang telah disajikan dalam transkrip catatan lapangan. Kegiatan reduksi data ini bertujuan untuk melihat kesalahan jawaban siswa dalam menjawab tes wawancara yang dilakukan oleh guru atau peneliti.

\section{Paparan data}

Paparan data adalah proses penampilan data secara sederhana dalam tabel frekuensi ataupun grafik, dan sebagainya.

\section{Penyimpulan data}

Penyimpulan data adalah proses pengambilan intisari dari data yang sudah terorganisasikan tersebut dalam bentuk pernyataan kalimat atau formula yang singkat dan padat tetapi mengandung pengertian yang luas. Penarikan kesimpulan untuk mengetahui persentase kemampuan siswa sebagai hasil pengukuran ketuntasan kompetensi siswa yang telah ditetapkan oleh TK Pertiwi Pompanua Kabupaten Bone digunakan rumus menurut pendapat Jadmiko, (2003:19) yaitu sebagai berikut:

Keterangan :

PPH $=$ Persentase Penilaian Hasil

$\mathrm{B}=$ Skor yang diperoleh

$\mathrm{N}=$ Skor total

Kriteria:

$0 \%<\mathrm{PPH}<65 \%$ Siswa belum tuntas belajar.

$65 \%<\mathrm{PPH}<100 \%$ Siswa sudah tuntas dalam belajar.

Indikator keberhasilan penelitian ini adalah apabila instrumen-instrumen yang telah disiapkan pada tiap-tiap siklus dapat dilaksanakan dengan baik, aktivitas/kemandirian siswa dalam belajar meningkat, lebih dari $85 \%$ siswa yang mendapat nilai bintang $\geq 3$.

\section{HASIL DAN PEMBAHASAN}

Hasil penelitian dalam penelitian tindakan kelas ini dibedakan dalam tiga kegiatan, yaitu (1) pra tindakan, (2) siklus I, dan (3) siklus II.

Kegiatan pra tindakan yang dilakukan pada murid kelompok A TK Pertiwi Pompanua menemukan permasalahan yaitu motivasi/aktivitas belajar siswa rendah, sebagaimana ditunjukkan dalam rekapitulasi hasil observasi kemandirian belajar siswa berikut ini:

Tabel 4.1 Rekapitulasi Hasil Observasi

Kemandirian Belajar Pada Pra Tindakan

\begin{tabular}{clcc}
\hline Skor & Keterangan & Frekuensi & $\begin{array}{c}\text { Persentase } \\
\text { \% }\end{array}$ \\
\hline 1 & Tidak & 7 & 46.67 \\
\hline
\end{tabular}

\begin{tabular}{clcc}
\hline & mandiri & & \\
\hline 2 & $\begin{array}{l}\text { Kurang } \\
\text { mandiri }\end{array}$ & 6 & 40 \\
\hline 3 & Mandiri & 2 & 13.33 \\
\hline 4 & $\begin{array}{l}\text { Sangat } \\
\text { mandiri }\end{array}$ & 0 & 0 \\
\hline & Jumlah & 15 & 100 \\
\hline
\end{tabular}

Berdasarkan hasil tersebut, masih terlalu banyak siswa yang tidak mandiri dan kurang mandiri dalam belajar, yaitu sebesar $46.67 \%$ dan $40 \%$ atau $86.67 \%$

Sedangkan sikap siswa terhadap kegiatan pembelajaran juga kurang baik, sebagaimana ditunjukkkan oleh tabel rekapitulasi hasil observasi sikap siswa berikut:

Tabel 4.2 Rekapitulasi Hasil Observasi Sikap Siswa Pada Pra Tindakan

\begin{tabular}{|c|l|c|c|}
\hline Skor & Keterangan & Frekuensi & Persentase\% \\
\hline 1 & Tidak senang & 7 & 46.67 \\
\hline 2 & Kurang senang & 5 & 33.33 \\
\hline 3 & Senang & 3 & 20 \\
\hline 4 & Sangat senang & 0 & 0 \\
\hline & Jumlah & 15 & 100 \\
\hline
\end{tabular}

Berdasarkan perhitungan dalam rekapitulasi hasil observasi sikap siswa tersebut dapat diketahui bahwa sebagian besar siswa bersikap tidak/kurang senang terhadap kegiatan belajar mengajar sebagaimana ditunjukkan oleh jumlah frekuensi siswa sebesar 12 atau $80 \%$.

Berdasarkan hasil pengamatan kemandirian belajar, sikap belajar dan hasil tes awal yang dikategorikan masih rendah atau masih mengalami kesulitan, maka selanjutnya dilakukan pembelajaran dengan kegiatan belajar sambil bermain dengan kegiatan menggambar sesuai keinginan siswa tanpa bantuan guru. Setelah pembelajaran selesai maka dilakukan observasi terhadap kemandirian belajar siswa dan pos tes untuk mengetahui hasil belajar siswa. Adapun hasil observasi kemandirian belajar, sikap belajar dan perolehan nilai siswa pada tes I dapat dilihat pada tabel di bawah ini:

Tabel 4.4 Rekapitulasi Hasil Observasi

Kemandirian Belajar Pada Siklus I

\begin{tabular}{|c|l|c|c|}
\hline Skor & Keterangan & Frekuensi & Persentase \% \\
\hline 1 & $\begin{array}{l}\text { Tidak } \\
\text { mandiri }\end{array}$ & 3 & 20 \\
\hline 2 & Kurang & 4 & 26.67 \\
\hline
\end{tabular}




\begin{tabular}{|c|l|c|c|}
\hline & mandiri & & \\
\hline 3 & Mandiri & 7 & 46.67 \\
\hline 4 & $\begin{array}{l}\text { Sangat } \\
\text { mandiri }\end{array}$ & 1 & 6.66 \\
\hline & Jumlah & 15 & \\
\hline
\end{tabular}

Berdasarkan hasil tersebut, sebagian besar siswa sudah mandiri dalam belajar, yaitu sebesar $46.67 \%$ dan $6,66 \%$ sangat mandiri, atau secara keseluruhan sebesar $53.33 \%$.

Sedangkan sikap siswa terhadap kegiatan pembelajaran, sebagaimana ditunjukkan oleh tabel rekapitulasi hasil observasi sikap siswa berikut ini.

Tabel 4.5 Rekapitulasi Hasil Observasi Sikap Siswa Pada Siklus I

\begin{tabular}{|c|l|c|c|}
\hline Skor & Keterangan & Frekuensi & $\begin{array}{c}\text { Persentase } \\
\%\end{array}$ \\
\hline 1 & Tidak senang & 2 & 13,33 \\
\hline 2 & Kurang senang & 5 & 33,33 \\
\hline 3 & Senang & 7 & 46,67 \\
\hline 4 & Sangat senang & 1 & 6,67 \\
\hline & Jumlah & 15 & 100 \\
\hline
\end{tabular}

Berdasarkan perhitungan dalam rekapitulasi hasil observasi sikap siswa tersebut dapat diketahui bahwa sebagian besar siswa sudah merasa senang terhadap kegiatan belajar mengajar sebagaimana ditunjukkan oleh jumlah frekuensi sebesar 8 atau 53.33.

Selanjutnya setelah selesai pembelajaran siklus I yang menerapkan strategi pembelajaran indoor learning dan outdoor learning dengan metode bermain, maka diberikan pos tes untuk mengetahui hasil belajar siswa. Dari pos tes siklus I diperoleh hasil bahwa masih ada beberapa siswa yang memiliki nilai bintang di bawah 3. Diketahui juga nilai rata-rata pada saat pos tes I dari 15 murid adalah 2,53. Namun demikian jika dibandingkan dengan nilai perolehan pada pra siklus menunjukkan adanya peningkatan hasil belajar. Untuk memperoleh hasil belajar yang lebih baik lagi, maka guru kelompok A TK Pertiwi Pompanua Kabupaten Bone kembali melaksanakan perbaikan pembelajaran pada siklus II. Hal ini dimaksudkan untuk lebih memantapkan proses pembelajaran pada siklus II, terutama difokuskan pada pengembangan aspek kemandirian siswa.

Adapun hasil observasi kemandirian belajar dan sikap belajar siswa serta perolehan nilai dan skor pada saat pos tes II dapat dilihat pada tabel di bawah ini:

Tabel 4.7 Rekapitulasi Angket Kemandirian Belajar Pada Siklus II

\begin{tabular}{|c|l|c|c|}
\hline Skor & \multicolumn{1}{|c|}{ Keterangan } & Frekuensi & $\begin{array}{c}\text { Persentase } \\
\%\end{array}$ \\
\hline 1 & Tidak mandiri & 0 & 0 \\
\hline 2 & $\begin{array}{l}\text { Kurang } \\
\text { mandiri }\end{array}$ & 2 & 13.33 \\
\hline 3 & Mandiri & 7 & 46.67 \\
\hline 4 & Sangat mandiri & 6 & 40 \\
\hline & Jumlah & 15 & \\
\hline
\end{tabular}

Berdasarkan hasil observasi tersebut, menunjukkan sebagian besar siswa sudah mandiri dalam belajar, yaitu sebanyak 7 siswa atau sebesar $46.67 \%$ mandiri dan sebanyak 6 siswa atau sebesar $40 \%$ sangat mandiri, atau jumlah keseluruhan kemandirian siswa sebesar $86.67 \%$.

Demikian pula sikap siswa terhadap kegiatan pembelajaran menunjukkan peningkatan, sebagaimana ditunjukkan oleh tabel rekapitulasi hasil pengamatan sikap siswa berikut ini :

Tabel 4.8 Rekapitulasi Hasil Observasi Sikap Siswa Pada Siklus II

\begin{tabular}{|c|l|c|c|}
\hline Skor & Keterangan & Frekuensi & $\begin{array}{c}\text { Persentase } \\
\%\end{array}$ \\
\hline 1 & Tidak senang & 0 & 0 \\
\hline 2 & Kurang senang & 2 & 13.33 \\
\hline 3 & Senang & 6 & 40 \\
\hline 4 & Sangat senang & 7 & 46.67 \\
\hline & Jumlah & 15 & 100 \\
\hline
\end{tabular}

Berdasarkan perhitungan dalam rekapitulasi hasil observasi sikap siswa tersebut dapat diketahui bahwa sebagian besar siswa sudah merasa senang terhadap kegiatan belajar mengajar, yaitu $40 \%$ senang dan $46.67 \%$ sangat senang, atau jumlah keseluruhan sebesar $86.67 \%$.

Setelah dilakukan pembelajaran pada siklus II menunjukkan peningkatan hasil belajar siswa yang cukup signifikan. Jika dilihat perolehan nilai rata-rata dari 15 murid pada siklus II (postes II) diperoleh 3.33. Hal ini menunjukkan adanya peningkatan hasil belajar siswa. Jika dilihat perolehan nilai mulai dari tes awal sampai ke siklus II dapat diketahui bahwa nilai rata-rata siswa pada saat diadakan tes awal adalah 1.93 dan siswa yang tuntas belajar adalah $20 \%$. Sedangkan saat pos tes pada siklus I dilaksanakan nilai rata- 
rata siswa meningkat menjadi 2.53 dan siswa yang tuntas belajar adalah $60 \%$. Kemudian pada pos tes siklus II nilai rata-rata siswa meningkat menjadi 3.33 dan siswa yang tuntas belajar adalah $86.67 \%$. Dengan demikian, dapat dinyatakan bahwa kemampuan siswa meningkat dalam pengembangan aspek kemandirian dengan menerapkan strategi outdoor learning dan indoor learning dengan menggunakan metode permainan. Sehingga dalam hal ini peneliti tidak perlu lagi melanjutkan pada siklus selanjutnya.

Suatu PTK dilaksanakan dengan beberapa siklus. Pada penelitian ini peneliti menjalankan dua siklus untuk mencapai hasil yang diinginkan.

\section{Siklus I}

a. Rencana (Planning)

Dalam penelitian ini kegiatan awal yang dilakukan peneliti adalah konsultasi dengan guru dan Kepala Sekolah TK Pertiwi Pompanua Kabupaten Bone, lalu menyusun rencana pelaksanaan pembelajaran tentang pengembangan aspek kemandirian murid. Kemudian peneliti membuat lembar observasi dan lembar kerja siswa sebagai alat untuk mengumpulkan data tentang sikap dan hasil belajar siswa.

b. Tindakan (Action)

Sebelum menerapkan strategi pembelajaran indoor learning dan outdoor learning terlebih dahulu peneliti dan guru kelompok A TK Pertiwi Pompanua Kabupaten Bone melaksanakan tes awal untuk mengetahui pengetahuan awal murid. Setelah itu pembelajaran dimulai dengan mengenalkan langkah-langkah kegiatan pembelajaran, dan peraturan dalam bermain (demonstrasi). Kemudian peneliti dan guru kelompok memberikan lembar kerja siswa serta bahan-bahan untuk alat peraga kepada siswa yang telah dibagi dalam 3 kelompok. Guru berkeliling memantau dan membimbing siswa serta memberikan penjelasan bagi kelompok yang belum paham atau kelompok yang mengalami kesulitan dalam menyelesaikan tugas.

c. Observasi (Obsevation)

Observasi dilaksanakan oleh peneliti sendiri pada saat proses pembelajaran berlangsung. Observasi dilakukan untuk melihat aktivitas guru dan siswa dalam proses pembelajaran yang menggunakan strategi indoor learning dan outdoor learning dengan metode bermain.

\section{d. Refleksi (Reflection)}

Pada akhir siklus diadakan refleksi terhadap hasil-hasil yang diperoleh peneliti melalui kegiatan bermain (demonstrasi), dan selanjutnya dilakukan pos tes untuk mengetahui pemahaman siswa mengenai materi pokok menggambar dalam pengembangan bakat kemandirian siswa kelompok A TK Pertiwi Pompanua Kabupaten Bone. Dari tes awal ke siklus I dapat direfleksikan nilai perolehan siswa.

\section{Siklus II}

a. Rencana (Planning)

Perolehan nilai siswa yang diperoleh pada siklus I terdapat beberapa siswa yang memiliki nilai masih dibawah bintang 3. Hal ini menunjukkan bahwa siswa masih kurang mampu membuat gambar yang tersedia atau bakat kemandirian masih tergolong rendah. Dengan demikian peneliti dan guru kelompok A TK Pertiwi Pompanua Kabupaten Bone kembali melakukan pembelajaran melalui siklus II dengan lebih memfokuskan pada penyelesaian tugas-tugas yang berhubungan dengan tes yang diberikan agar tercapai target yang diinginkan.

b. Tindakan (Action)

Pembelajaran dengan kegiatan bermain/ demonstrasi yang telah disusun oleh peneliti dan guru kelompok A TK Pertiwi Pompanua Kabupaten Bone diharapkan dapat meningkatkan hasil belajar murid. Melalui kegiatan ini siswa lebih difokuskan untuk dapat menyelesaikan tugas-tugas yang telah diberikan berupa gambar.

c. Observasi (Observation)

Pada kegiatan belajar mengajar terlihat aktivitas siswa meningkat khususnya dalam menyelesaikan tugas-tugas yang diberikan guru.

d. Refleksi (Reflection)

Setelah pelaksanaan pembelajaran pada siklus II berakhir, peneliti dan guru kelompok A TK Pertiwi Pompanua Kabupaten Bone kembali melakukan pos tes untuk mengetahui tingkat pemahaman siswa.

Setelah dilakukan pembelajaran pada siklus II dan dilakukan pos tes diperoleh peningkatan hasil belajar siswa kelompok A TK Pertiwi Pompanua Kabupaten Bone pada materi menggambar untuk pengembangan bakat kemandirian dengan menggunakan metode bermain dengan outdoor dan indoor learning. Dengan adanya peningkatan nilai rata-rata siswa dari pos tes I ke pos tes II sebesar 0,8 dan juga 
sekaligus menandakan bahwa tidak perlu lagi dilaksanakan perbaikan pembelajaran.

Berdasarkan dari tes awal, pos tes I dan pos tes II menunjukkan adanya peningkatan hasil belajar siswa. Nilai rata-rata siswa pada tes awal 1.93 atau ketuntasan sebesar $20 \%$, pos tes I sebesar 2.53 atau ketuntasan sebesar $60 \%$ dan pos tes II sebesar 3.33 atau ketuntasan sebesar $86.67 \%$.

Untuk lebih jelasnya peningkatan hasil belajar dan ketuntasan siswa dapat dilihat pada chart berikut:

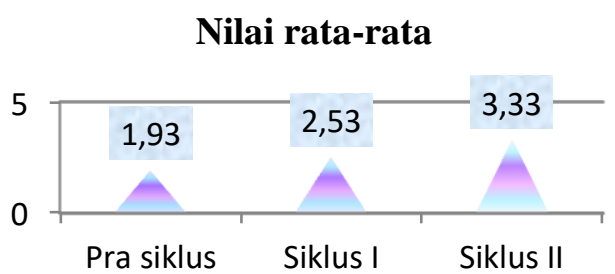

Ketuntasan

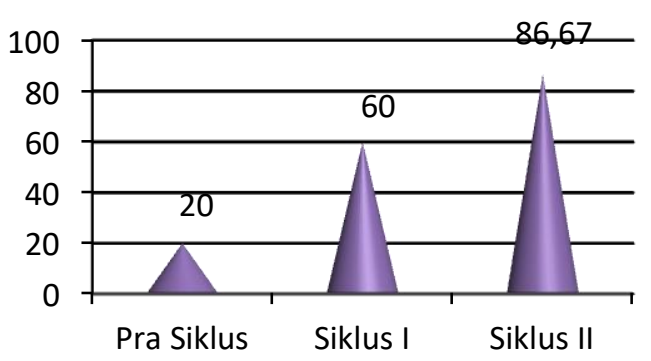

Demikian pula dari aspek kemandirian anak mengalami peningkatan. Pada pra tindakan kemandirian anak hanya $13.33 \%$ mandiri atau sebesar $86.67 \%$ yang tidak/kurang mandiri, kemudian pada siklus I meningkat menjadi $53.33 \%$ mandiri, dan pada siklus II menjadi $86.67 \%$ anak yang mandiri. Untuk lebih jelasnya dapat dilihat pada grafik berikut.

\section{Kemandirian Siswa}

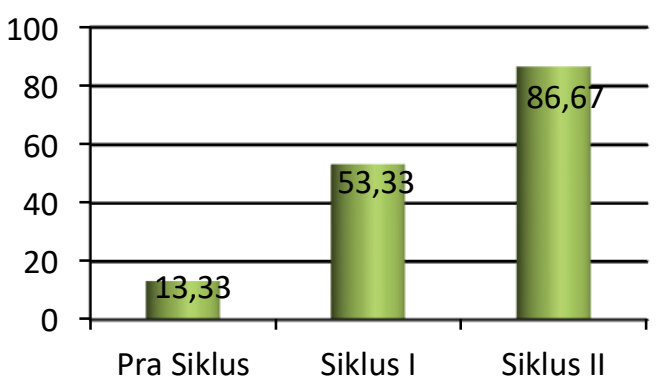

Dengan demikian pembelajaran melalui penerapan strategi outdoor learning dan indoor learning dengan metode permainan dapat meningkatkan kemandirian dan hasil belajar siswa kelompok A TK Pertiwi Pompanua Kabupaten Bone.

\section{SIMPULAN DAN SARAN}

Berdasarkan penelitian yang disajikan dalam BAB IV dapat diambil kesimpulan bahwa:

1. Pembelajaran dengan strategi outdoor dan indoor learning dengan menggunakan metode bermain dapat meningkatkan hasil belajar siswa.

2. Dari hasil pelaksanaan siklus I diperoleh tingkat ketuntasan belajar sebesar $60 \%$, dan tingkat kemandirian siswa sebesar $53.33 \%$.

3. Dari hasil pelaksanaan siklus II diperoleh tingkat ketuntasan belajar sebesar $86.67 \%$, dan tingkat kemandirian siswa sebesar $86.67 \%$.

Berdasarkan temuan penelitian yang telah disajikan pada BAB IV maka disarankan:

1. Bagi guru yang menerapkan strategi pembelajaran outdoor dan indoor learning dengan menggunakan metode bermain hendaknya lebih teliti dalam penggunaannya, lebih sabar dan memperhatikan alokasi waktu yang ada.

2. Diharapkan kepada semua guru mata pelajaran untuk sedapat mungkin menguasai berbagai metode mengajar dan alternatif strategi mengajar lainnya, agar dalam proses pembelajaran tidak hanya menggunakan satu jenis metode mengajar untuk meningkatkan hasil belajar siswa.

3. Kepada peneliti selanjutnya, kiranya dapat mengadakan penelitian lanjutan untuk mendapatkan hasil yang lebih luas dan lebih baik.

\section{DAFTAR RUJUKAN}

Ahmadi, Abu, dkk. 2005. Strategi Belajar Mengajar. Bandung: Pustaka Setia

Agustina. 2006. Magic Mathic's I. Semarang: Penerbit Andi.

Arikunto, Suharsimi, dkk, 2008. Penelitian Tindakan Kelas. Jakarta: Bumi Aksara.

Dewi, Rosmala dan Irsan, 2003. Penelitian Tindakan Kelas. Fakultas Ilmu Pendidikan

Djamarah, S.B. dkk, 2006, Strategi Belajar Mengajar. Jakarta: Rineka Cipta 
JIKAP PGSD: Jurnal Ilmiah Ilmu Kependidikan

Enco, Mulyoso. 2007. Menjadi Guru Profesional. Bandung: PT. Remaja Rosdakarya.

Gordon, Thomas. 1990. Guru Yang Efektif. Jakarta: PT Raja Grafindo Persada.

Jadmiko, B. 2003. Penelitian Tindakan Kelas (PTK), Jakarta: Depdikbud.

Lask, Bryan. 1991. Memahami dan Mengatasi Masalah Anak Anda. Jakarta: PT Gramedia Pustaka Utama.

Malik, Fadjar. 2003. Undang-undang Sistem Pendidikan Nasional. Jakarta: Sinar Grafika.

Rochiati, Wiriaatmadja. 2007. Metode Penelitian Tindakan Kelas. Bandung: Rosda.

Sardiman. 2003. Interaksi \& Motivasi Belajar Mengajar . Jakarta: Raja Grafindo Persada

Sugianto, Mayke. 1995. Bermain, mainan dan permainan. Jakarta: Departemen Pendidikan dan Kebudayaan.

Suryosubroto. 2002. Proses Belajar Mengajar di Sekolah. Jakarta: Rineka Cipta 